\title{
PENERAPAN BLENDED-PROBLEM BASED LEARNING DI MASA PANDEMI UNTUK MENINGKATKAN CRITICAL THINKING MAHASISWA PENDIDIKAN GURU SEKOLAH DASAR
}

\author{
Rafhi Febryan Putera1, Ainun Mahfuzah² , Farida s ${ }^{3}$, \\ M. Habibi ${ }^{4}$, Puguh Iskandar ${ }^{5}$ \\ $1,3,4$ universitas Negeri Padang, Indonesia, ${ }^{2}$ Universitas Negeri Yogyakarta, \\ Indonesia ${ }^{5}$ Universitas PGRI Yogyakarta, Indonesia. \\ Email: rafhifebryan@ @ip.unp.ac.id ${ }^{1}$, ainunmahfuzah.2019@ student.uny.ac.id², \\ faridasuarman1960@gmail.com ${ }^{3}$ habibie91@fip.unp.ac.id ${ }^{4}$,puguhiskandar@upy.ac.id ${ }^{5}$
}

\begin{abstract}
The Covid pandemic requires blended learning (a combination of face-to-face and online learning). The low ability to think critically in class makes the learning process not optimal, therefore it is necessary to increase students' critical thinking skills using the Blended-Problem Based Learning learning model. The method used is classroom action research with a sample of 73 semester VI students in the learning media course for Primary School Teacher Education at Padang State University. Students 'initial critical thinking ability was in the very poor category with a percentage of $41 \%$, after the first cycle there was an increase in students' critical thinking skills by $15 \%$ and cycle II by $27 \%$. It can be concluded that the Blended-Problem Based Learning learning model can improve students' critical thinking skills
\end{abstract}

Keywords : Blended-Problem Based Learning, Critical Thinking

\begin{abstract}
ABSTRAK
Pandemi Covid membutuhkan pembelajaran campuran (kombinasi pembelajaran tatap muka dan online). Rendahnya kemampuan berpikir kritis di kelas membuat proses pembelajaran tidak maksimal, oleh karena itu perlu dilakukan peningkatan kemampuan berpikir kritis siswa dengan menggunakan model pembelajaran Blended-Problem Based Learning. Metode yang digunakan adalah penelitian tindakan kelas dengan sampel sebanyak 73 siswa semester VI pada mata kuliah media pembelajaran Pendidikan Guru Sekolah Dasar Universitas Negeri Padang. Kemampuan berpikir kritis awal siswa berada pada kategori sangat buruk dengan persentase $41 \%$, setelah siklus I terjadi peningkatan kemampuan berpikir kritis siswa sebesar $15 \%$ dan siklus II sebesar 27\%. Dapat disimpulkan bahwa model pembelajaran Blended-Problem Based Learning dapat meningkatkan kemampuan berpikir kritis siswa
\end{abstract}

Kata Kunci: Blended-Problem Based Learning, Berpikir Kritis

\section{PENDAHULUAN}

Pandemi Covid 19 telah terjadi sejak Desember 2019 lalu, (Jandrić, 2020) ia menyampaikan bahwa pandemi covid 19 ini telah menyentuh angka 118.000 kasus dan 110 negara, tentu saja hal ini berdampak terhadap seluruh sektor kehidupan ummat manusia tak terkecuali dibidang pendidikan, kondisi pendidikan di Indonesia yang sejak awal maret tahun 2020 ini wajib belajar dari rumah dengan menggunakan berbagai platform, platform e-learning maupun blended learning menjadi salah satu alternatif untuk mengatasi permasalahan mahasiswa yang tidak dapat belajar secara penuh di kampus (Herliandry et al., 2020). Hal ini semata-mata bertujuan mencapai kompetensi abad 21 dimana hendaknya mahasiswa dapat menyeimbangkan antara soft skills dan hards skills dalam kondisi apapun dengan mengasah 3 aspek, yaitu: sikap, pengetahuan, dan keterampilan (Kemendikbud RI, 2014) (Zubaidah, 2018) selain itu kompetensi pada 
abad ke-21 juga menekankan pada 4C meliputi Berpikir Kritis (critical thingking), kerjasama (collaboration), komunikasi (communication), dan Media Pembelajaran (creativity)(Sumarno, 2019)(Sari, Suci Perwita; Siregar, 2020).

(KRISTINA PERONIKA NAIBAHO, 2020) Kemajuan dunia pendidikan menciptakan manusiamanusia bermartabat mulia yang memiliki potensi tinggi untuk kemajuan bangsa, sehingga dapat meningkatkan mutu pendidikan. Pendidikan tidak pernah lekang dari setiap manusia karena pendidikan adalah sesuatu hal yang sangat penting. Dalam rangka menunjang kompetensi abad 21 tersebut pemilihan model pembelajaran juga menjadi sebuah alasan untuk tetap mengasah kemampuan berpikir kritis mahasiswa. Dalam hal ini PBL menjadi sebuah model yang dapat dipadukan dalam pembelajaran tatap muka dan online (blended learning) (Sari, 2013)(Prayitno, 2015). Dengan blended-PBL diharapkan mahasiswa dapat memecahkan masalah dengan beragam alternatif solusi, serta dapat mengidentifikasi penyebab permasalahan yang ada baik melalui tanya jawab secara langsung maupun online (Sudarman, 2007).

Masalah yang dimunculkan dalam pembelajaran PBL tidak memiliki jawaban yang tunggal, artinya para mahasiswa harus terlibat dalam eksplorasi dengan beberapa jalur solusi (Hmelo-Silver \& Barrows, 2006). Keterlibatan mahasiswa dalam PBL ini dapat membantu dalam mengembangkan kemampuan Berpikir Kritis (Ommundsen, 2013)(Yazar Soyad1, 2015), karena pada pembelajaran PBL mahasiswa terlibat penuh dalam proses pembelajaran melalui kegiatan pemecahan masalah. Pada kegiatan memecahkan masalah inilah mahasiswa dituntut untuk dapat mengembangkan kemampuan Berpikir Kritis sebagai langkah memecahkan permasalahan yang dibahas serta dapat mengambil kesimpulan berdasarkan pemahaman mereka.

Pembelajaran dengan menggunakan pendekatan blended learning berbasis permasalahan seperti Blended-PBL efektif dalam meningkatkan kecakapan Berpikir Kritis. Penggunaan Blended-Problem Based Learning yang berbasis permasalahan dapat meningkatkan kemampuan Berpikir Kritis (Triyanto et al., 2016). Blended-PBL signifikan dalam meningkatkan High Order Thinking Skills, termasuk Berpikir (Şendağ \& Ferhan Odabaşi, 2009). Potensi-potensi tersebut dapat digunakan sebagai dasar pemilihan Blended-PBL sebagai model pembelajaran untuk mengembangkan kecakapan Berpikir Kritis.

Kemampuan berpikir kritis setiap individu berbeda-beda, tergantung pada latihan yang sering dilakukan. Kenyataan yang ditemui pada mahasiswa semester tujuh PGSD Universitas Negeri Padang, menunjukkan bahwa dalam mempelajari tentang media pembelajaran mereka masih teoritis dan kurang mengembangkan kemampuan berpikir kritis. Keantusiasan mahasiswa dalam menjawab pertanyaan yang diajukan dosen masih terbatas secara teori belum menunjukkan pengembangan yang sesuai dengan potensi serta kemampuan mereka. Selain itu, terdapat beberapa mahasiswa yang masih sulit dalam bekerja secara berkelompok, berkomunikasi, memecahkan masalah ketika diajukan contoh suatu permasalahan nyata, mencoba mencari alternatif jawaban pemecahan masalah dari media online, serta belum bisa mengambil keputusan sebagai solusi yang tepat dari suatu permasalahan.

Kemampuan Berpikir Kritis adalah pertimbangan yang aktif, terus-menerus dan teliti mengenai sebuah keyakinan atau bentuk pengetahuan yang diterima begitu saja dengan menyertakan alasan yang mendukung dan kesimpulan-kesimpulan yang rasional(Holmes et al., 2015)(Enis, 1993). Artinya berpikir kritis sama dengan berpikir aktif. Orang yang berpikir aktif memiliki ciri-ciri berpikir secara terus-menerus dan teliti. Hal ini dapat diartikan bahwa orang yang Berpikir Kritis akan terus aktif mengoptimalkan daya nalarnya. 
Kemampuan critical thinking juga di defenisikan sebagai: 1) suatu sikap mau berpikir secara mendalam tentang masalah-masalah dan hal-hal yang berada dalam jangkauan pengalaman seseorang; 2) pengetahuan tentang metode-metode pemeriksaan penalaran yang logis; 3) semacam keterampilan menerapkan metode-metode tersebut (Shamim, 2017)(Horvath \& Forte, 2011). Berpikir Kritis menuntut upaya keras untuk memeriksa setiap keyakinan atau pengetahuan asumtif berdasarkan bukti pendukungnya dan kesimpulan-kesimpulan lanjutan yang diakibatkannya

Berdasarkan pernyataan tersebut dapat kita pahami bahwa Berpikir Kritis berarti berpikir secara mendalam sehingga pemikir bisa membuat perbedaan antara ideide, menemukan hubungan antara mereka, menyadari di mana bagian dari ide hidup dalam suatu sistem (atau apa gagasan itu adalah bagian dari) dan mengambil berbagai perspektif untuk lebih memahami ide dari sudut pandang yang berbeda .

Blended learning merupakan pembelajaran yang mengkombinasikan atau menggabungkan berbagai teknologi berbasis web, untuk mencapai tujuan pendidikan (Driscoll, 2002). Sementara (Graham, 2011)(Smaldino \& McElreath, 2016) menyebutkan blended learning secara lebih sederhana sebagai pembelajaran yang mengkombinasikan antara pembelajaran online dengan face-to-face (pembelajaran tatap muka)(Garrison \& Vaughan, 2012)(Etherington, 2011). Blended learning adalah sebuah kemudahan pembelajaran yang menggabungkan berbagai cara penyampaian, model pengajaran, dan gaya pembelajaran, memperkenalkan berbagai pilihan media dialog antara fasilitator dengan orang yang mendapat pengajaran. Blended learning juga sebagai sebuah kombinasi pengajaran langsung (face-to-face) dan pengajaran online, tapi lebih daripada itu sebagai elemen dari interaksi sosial.

Pembelajaran berbasis masalah (PBL) adalah pembelajaran yang berpusat pada peserta didik dengan pendekatan masalah pada analisis, pemecahan dan diskusi tentang masalah yang diberikan (Cazzola, 2008)(Yaman \& Graf, 2010). Ini dapat diterapkan untuk berbagai mata pelajaran. (Arends \& Kilcher, 2010) mengemukakan PBL membantu perkembangan siswa dalam berpikir dan memecahkan masalah, mempelajari peranan orang dewasa dan kemampuan bersosialisasi, serta kemampuan untuk belajar mandiri. PBL adalah model pembelajaran yang mengarahkan mahasiswa untuk menemukan fakta dan konsep dari pemecahan masalah autentik yang dihadapi Permasalahan autentik yang berhubungan dengan kehidupan sehari-hari merupakan kekuatan yang dimiliki oleh PBL dan dimanfaatkan sebagai stimulus untuk belajar (Etherington, 2011)(Wood, 2008). Permasalahan dalam PBL digunakan mahasiswa untuk menemukan tujuan pembelajaran mereka sendiri.

Dari penjelasan di atas dapat dilihat bahwa salah satu model pembelajaran yang dapat mengatasi masalah rendahnya kemampuan berfikir kritis mahasiswa dimasa pandemi covid 19 adalah dengan model pembelajaran Blended-PBL. Oleh karena itu penulis menggunakan model pembelajaran ini dalam penelitian tindakan kelas yang dilakukan pada mata kuliah media pembelajaran mahasiswa semester VI Jurusan Pendidikan Guru Sekolah Dasar FIP UNP?

\section{METODE PENELITIAN}

Penelitian ini menggunakan metode penelitian tindakan kelas (classroom action research), yaitu penelitian yang bersifat kolaboratif (Sugiono, 2016). Populasi penelitian ini adalah seluruh mahasiswa Jurusan Pendidikan Guru Sekolah Dasar FIP UNP Tahun ajaran 2020/2021. Sedangkan sampel dalam penelitian ini adalah 70 orang mahasiswa semester VI kelas A dan B Jurusan Pendidikan Guru Sekolah Dasar FIP UNP yang sedang mengambil matakuliah Media Pembelajaran dalam Pembelajaran. 
Penelitian Tindakan Kelas ( PTK) ini salah satu alternatif penelitian terapan untuk meningkatkan dan memperbaiki kinerja pembelajaran di kelas atau lapangan yang dilaksanakan dengan mengikuti prosedur yang menyatakan bahwa dalam satu Siklus terdiri atas empat langkah: "perencanaan (planning), pelaksanaan (acting), observasi (observing), dan refleksi (reflecting) (Kemmis et al., 2014)(Putera et al., 2018).

Dalam hal ini penelitian akan dilakukan sedikitnya 2 siklus, yang tiap siklusnya terdiri dari 2 kali pertemuan terhadap subjek yang diteliti. Tahap-tahap penelitian berikutnya dilakukan secara sistematis seperti:

1. Tahap Perencanaan

Yakni membuat rencana secara keseluruhan berdasarkan pada temuan awal yakni berupaya untuk memperbaiki kualitas proses pembelajaran melalui model pembelajaran berbasis proyek yang digunakan dalam matakuliah Media Pembelajaran dalam Pembelajaran, meliputi tugas-tugas yang dilakukan pada setiap siklus selama penelitian.

2. Tahap Pelaksanaan Tindakan

Yakni melaksanakan rencana yang disusun bersama tim dengan dukungan bahan dan media yang sudah disiapkan. Semua tindakan baik pada siklus 1 dan siklus 2 diimplementasikan pada satu kelas pelaksana tindakan adalah peneliti yang merupakan team teaching.

3. Tahap Pengamatan

Tahap ini dilakukan bersamaan dengan implementasi tindakan. Pada tahap ini dilakukan observasi terhadap berlangsungnya tindakan dan efek yang ditimbulkan oleh tindakan tersebut, baik oleh mahasiswa atau dosen maupun sistem pembelajaran secara keseluruhan. Observasi dilakukan oleh kolabolator (anggota team teaching) dan juga oleh peneliti langsung pada saat melaksanakan pembelajaran

4. Tahap Refleksi

Tahap ini merupakan tahap evaluasi dan refleksi terhadap hasil monitoring yang telah dilakukan, baik proses maupun produk pembelajaran, didiskusikan bersama dengan tim peneliti secara objektif dan terbuka seperti komentar, tanggapan, dan penilaian diintegrasikan guna mengukur keberhasilan pelaksanaan pembelajaran, pada siklus pertama, baik yang berhubungan dengan strategi pembelajaran, maupun konten pembelajaran (bidang pengembangan), selanjutnya disimpulkan tingkat keberhasilannya. Bila belum sampai pada tingkat keberhasilan yang diinginkan, maka dicari penyebabnya, kemudian diadakan perbaikan dan tindak lanjut pada siklus berikutnya, dan seterusnya.(Rose \& Grosvenor, 2013)(Putera \& Qalbi, 2020)

\section{HASIL PENELITIAN DAN PEMBAHASAN}

Berdasarkan pengamatan awal dan diskusi dengan tim dosen pengampu mata kuliah Media pembelajaran diperoleh gambaran mengenai kondisi pembelajaran di kelas pada mahasiswa semester 6. Materi dalam mata kuliah Media pembelajaran disampaikan oleh dosen dengan menggunakan metode pembelajaran aktif dan memanfaatkan media online yaitu aplikasi zoom. Penerapan metode ini belum optimal untuk meningkatkan kemampuan berfikir kritis mahasiswa karena pada umumnya para dosen masih menggunakan metode ceramah secara satu arah.

Dari observasi awal terlihat bahwa mahasiswa masih kurang mampu untuk memberikan contoh kasus di dalam pendidikan dasar dan di masyarakat, mahasiswa juga kurang bergairah dalam perkuliahan, malu bertanya dan mengungkapkan pendapat masing - masing individu dan kurangnya minat mahasiswa dalam mengerjakan tugas 
yang diberikan dosen. Apabila diadakan kuliah dengan tatap maya zoom, mahasiswa hanya mendengarkan saja, tidak muncul pertanyaan selama proses kuliah dan ketika ditanya oleh dosen tidak ada yang berbicara. Kondisi ini menunjukkan kurangnya kemampuan berpikir kritis mahasiswa khususnya pada mata kuliah Media pembelajaran.

Berdasarkan kondisi dan data awal tersebut diperlukan adanya tindakan untuk membantu mahasiswa dalam memahami materi untuk meningkatkan keterampilan berpikir kritis mahasiswa. Langkah yang diambil dalam penelitian ini yaitu dengan menerapkan model Blended-PBL yang diharapkan dapat meningkatkan peran aktif mahasiswa dalam pembelajaran sehingga dapat meningkatkan keterampilan berpikir kritis.

Berikut ini adalah hasil observasi awal mengenai kemampuan berfikir kritis mahasiswa pada perkuliahan Media pembelajaran.

Tabel 1. Hasil Tes Kemampuan Berfikir Kritis Awal

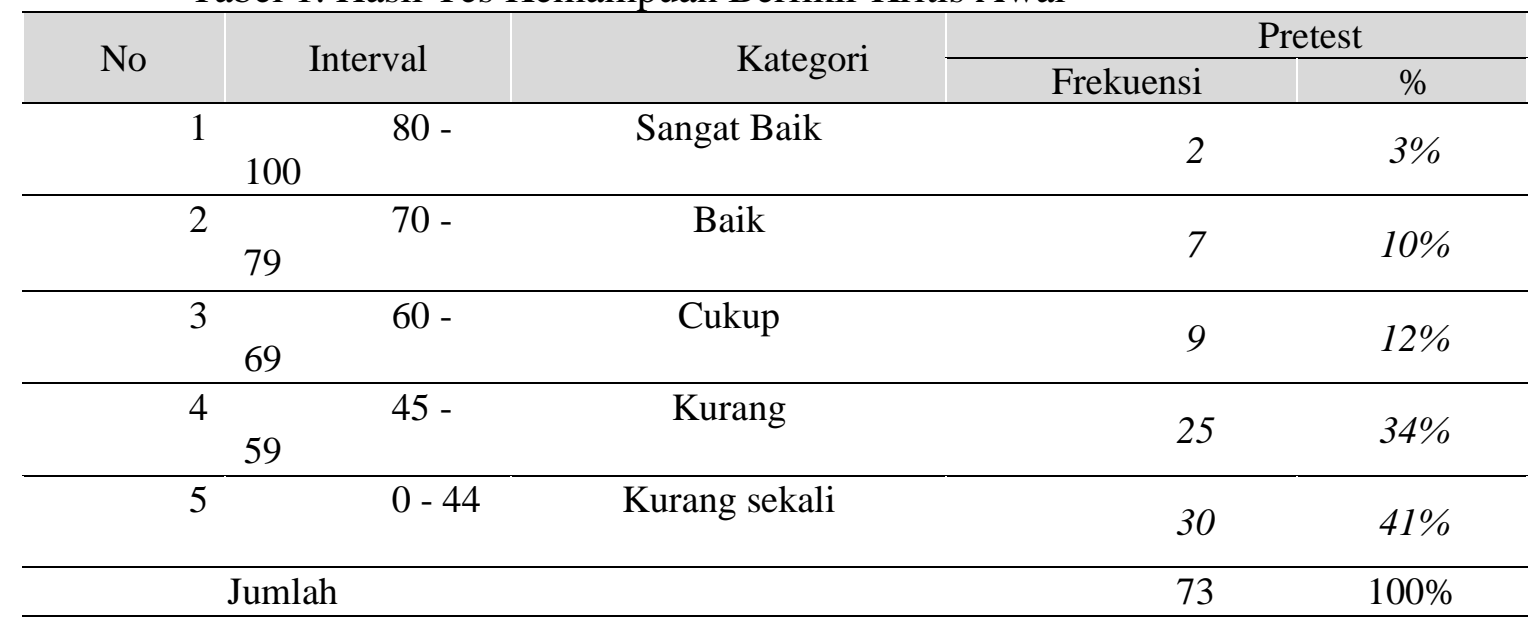

\section{Hasil Penelitian Siklus I}

Adapun kegiatan yang dilakukan selama proses pembelajaran pada siklus I meliputi tahap perencanaan, tindakan, pengamatan dan refleksi diuraikan sebagai berikut :

\section{a. Perencanaan (Planning)}

Pada siklus I peneliti menyampaikan materi mengenai konsep "Media Pembelajaran". Dalam tahapan ini peneliti menyampaikan tujuan pembelajaran yang hendak dicapai yaitu menerapkan model pembelajaran Blended-PBL untuk meningkatkan kemampuan berpikir kritis. Materi ajar yang digunakan bertujuan untuk memberikan pengetahuan dan wawasan pada mahasiswa tentang materi tersebut

b. Pelaksanaan (Acting)

Pada tahap pelaksanaan pada fase penelitian tindakan kelas ini peneliti memulai materi dengan memberikan apersepsi sebagai upaya untuk memberikan rangsangan kepada mahasiswa agar lebih siap dalam mengikuti perkuliahan. Peneliti menyampaikan tujuan pembelajaran yang ingin dicapai. Selanjutnya, peneliti menyampaikan topik mengenai konsep Media Pembelajaran selama 15 menit. Penjelasan peneliti ini diharapkan dapat merangsang kepekaan siswa terhadap masalah yang menjadi materi perkuliahan. Pada kegiatan ini, peneliti menyampaikan skenario pembelajaran mengenai pelaksanaan model pembelajaran berbasis masalah, yakni dengan memberikan tugas membuat resume tentang materi konsep Media Pembelajaran, lalu membuat sebuah peta konsep mengenai materi konsep Media 
Pembelajaran yang telah dipelajari yang dikumpulkan melalui aplikasi google classroom. Kemudian pertemuan berikutnya mahasiswa dipilih secara acak untuk mempresentasikan hasil pekerjaannya membuat resume dan peta konsep mengenai Media Pembelajaran dengan menggunakan aplikasi zoom. Pada 30 menit terakhir dilakukan diskusi dan tanya jawab tentang materi yang telah dibahas sebelumnya. Selama proses perkuliahan tentang materi konsep Media Pembelajaran diharapkan mahasiswa mengembangkan kemampuan berpikir kritis.

c. Pengamatan (Observing)

Selama siklus I berlangsung peneliti mengamati kemampuan berpikir kritis terhadap mahasiswa. Berdasarkan hasil diskusi yang ditulis di lembar kerja diskusi dan selama pelaksanaan pembelajaran dapat disimpulkan bahwa keterampilan berpikir kritis mahasiswa termasuk dalam kategori kurang sekali dengan persentase 26\%, kurang dengan persentase $34 \%$, cukup dengan persentase $22 \%$, baik dengan persentase $12 \%$, dan kategori sangat baik dengan persentase 5\%. Berikut ini adalah hasil observasi pada siklus I mengenai kemampuan berfikir kritis mahasiswa pada perkuliahan Media pembelajaran.

Tabel 2. Klasifikasi Kemampuan Berpikir Kritis Siklus I

\begin{tabular}{|c|c|c|c|c|}
\hline \multirow{2}{*}{ No } & \multirow{2}{*}{ Interval } & \multirow{2}{*}{ Kategori } & \multicolumn{2}{|c|}{ Postest } \\
\hline & & & Frekuensi & $\%$ \\
\hline 1 & $80-100$ & Sangat Baik & 4 & $5 \%$ \\
\hline 2 & $70-79$ & Baik & 9 & $12 \%$ \\
\hline 3 & $60-69$ & Cukup & 16 & $22 \%$ \\
\hline 4 & $45-59$ & Kurang & 25 & $34 \%$ \\
\hline 5 & $0-44$ & Kurang sekali & 19 & $26 \%$ \\
\hline & umlah & & 73 & 100 \\
\hline
\end{tabular}

\section{d. Refleksi (Reflecting)}

Berdasarkan indikator yang telah ditentukan, keterampilan berfikir kritis mahasiswa selama perkuliahan perlu ditingkatkan karena termasuk dalam kategori kurang sekali persentase $26 \%$, kurang dengan persentase $34 \%$, cukup dengan persentase $22 \%$, baik dengan persentase $12 \%$, dan kategori sangat baik dengan persentase $5 \%$. Oleh karena itu, peneliti merencanakan tindakan berikut pada siklus II karena pada siklus I belum mencapai target yang ditentukan sesuai dengan indikator tersedia.

\section{Hasil Penelitian Siklus II}

Adapun kegiatan yang dilakukan selama proses pembelajaran pada siklus II sama dengan proses pada siklus I meliputi tahap perencanaan, tindakan, pengamatan dan refleksi diuraikan sebagai berikut :

a. Perencanaan (Planning)

Pada siklus II peneliti menyampaikan materi mengenai "Strategi pembelajaran dalam mengembangkan media pembelajaran". Dalam tahapan ini peneliti menyampaikan tujuan pembelajaran yang hendak dicapai yaitu menerapkan model pembelajaran Blended-PBL untuk meningkatkan kemampuan berpikir kritis. Materi ajar yang digunakan bertujuan untuk memberikan pengetahuan dan wawasan pada mahasiswa tentang materi tersebut.

b. Pelaksanaan (Acting)

Pada tahap pelaksanaan pada fase penelitian tindakan kelas ini peneliti memulai materi dengan memberikan apersepsi sebagai upaya untuk memberikan rangsangan kepada mahasiswa agar lebih siap dalam mengikuti perkuliahan. Peneliti 
menyampaikan tujuan pembelajaran yang ingin dicapai. Selanjutnya, peneliti menyampaikan topik mengenai strategi pembelajaran dalam mengembangkan media pembelajaran selama 15 menit. Penjelasan peneliti ini diharapkan dapat merangsang kepekaan siswa terhadap masalah yang menjadi materi perkuliahan. Pada kegiatan ini, peneliti menyampaikan skenario pembelajaran mengenai pelaksanaan model pembelajaran berbasis masalah, yakni dengan memberikan tugas membuat modul tentang salah satu materi Strategi pembelajaran dalam mengembangkan media pembelajaran yaitu seni tari, lalu membuat sebuah video penciptaan tari sesuai dengan modul yang telah dibuat. modul dikumpulkan melalui aplikasi google classroom, tugas video di upload pada youtube. Kemudian pertemuan berikutnya mahasiswa dipilih secara acak untuk mempresentasikan hasil pekerjaannya membuat modul seni tari dengan menggunakan aplikasi zoom. Pada 30 menit terakhir dilakukan diskusi dan tanya jawab tentang materi yang telah dibahas sebelumnya. Selama proses perkuliahan tentang materi strategi pembelajaran dalam mengembangkan media pembelajaran diharapkan mahasiswa mengembangkan kemampuan berpikir kritis.

c. Pengamatan (Observing)

Selama siklus II berlangsung peneliti mengamati kemampuan berpikir kritis terhadap mahasiswa. Berdasarkan hasil diskusi yang ditulis di lembar kerja diskusi dan selama pelaksanaan pembelajaran dapat disimpulkan bahwa keterampilan berpikir kritis mahasiswa termasuk dalam kategori kurang sekali dengan persentase 14\%, kurang dengan persentase $14 \%$, cukup dengan persentase $34 \%$, baik dengan persentase $23 \%$, dan kategori sangat baik dengan persentase $15 \%$. Berikut ini adalah hasil observasi pada siklus II mengenai kemampuan berfikir kritis mahasiswa pada perkuliahan Media pembelajaran.

Tabel 2. Klasifikasi Kemampuan Berpikir Kritis Siklus II

\begin{tabular}{|c|c|c|c|c|}
\hline \multirow{2}{*}{ No } & \multirow{2}{*}{ Interval } & \multirow{2}{*}{ Kategori } & \multicolumn{2}{|c|}{ Postest } \\
\hline & & & Frekuensi & $\%$ \\
\hline 1 & $80-100$ & Sangat Baik & 11 & $15 \%$ \\
\hline 2 & $70-79$ & Baik & 17 & $23 \%$ \\
\hline 3 & $60-69$ & Cukup & 25 & $34 \%$ \\
\hline 4 & $45-59$ & Kurang & 10 & $14 \%$ \\
\hline 5 & $0-44$ & Kurang sekali & 10 & $14 \%$ \\
\hline \multicolumn{2}{|c|}{ Jumlah } & & 73 & 100 \\
\hline
\end{tabular}

d. Refleksi (Reflecting)

Berdasarkan hasil penelitian pada siklus II diperoleh analisis data yang nyata bahwa setelah adanya pembelajaran menggunakan model Blended-Problem Based Learning terlihat adanya suatu peningkatan kemampuan berfikir kritis pada mahasiswa.

Berdasarkan hasil observasi Blended-PBL pada tahapan awal diperoleh data bahwa bahwa keterampilan berpikir kritis mahasiswa termasuk dalam kategori kurang sekali dengan persentase $14 \%$, kurang dengan persentase $14 \%$, cukup dengan persentase $34 \%$, baik dengan persentase $23 \%$, dan kategori sangat baik dengan persentase $15 \%$. Pada tahapan tersebut peneliti sudah memberdayakan pertanyaan provokatif guna memancing kemampuan berpikir kritis mahasiswa selain itu perkuliahan yang sudah student centered sehingga mahasiswa menjadi aktif

Berdasarkan refleksi tindakan pembelajaran bersama peneliti dan observer, peneliti dapat meningkatkan persentase pencapaian pembelajaran siklus kedua, peneliti sudah melakukan semua indikator Blended-PBL sehingga terdapat peningkatan persentase kemampuan berpikir kritis mahasiswa dari siklus 1 ke siklus 2 dalam 
kategori kurang sekali dengan peningkatan persentase $8 \%$, kurang dengan persentase $20 \%$, cukup dengan persentase $12 \%$, baik dengan persentase $11 \%$, dan kategori sangat baik dengan persentase $10 \%$. Hal ini sesuai dengan pendapat (Wannapiroon, 2014) menjelaskan model Blended-PBL dapat mengembangkan pemikiran kritis mahasiswa terdiri dari prinsip, obyektif, proses pengajaran dan evaluasi.

Peningkatan ini disebabkan karena sebelum memasuki siklus II mahasiswa sudah memiliki pengalaman dan kemampuan awal yang diperoleh pada siklus I. Berdasarkan hasil penelitian pada siklus I dan II dapat dilihat bahwa dengan model Blended-PBL dalam proses pembelajaran, mahasiswa menunjukkan peningkatan dalam kemampuan berfikir kritis.

Hasil dalam penelitian ini sejalan dengan penelitian yang dilakukan oleh Penelitian yang dilakukan (Lukitasari et al., 2019) Berdasarkan hasil penelitian, kemampuan berfikir kritis dapat ditingkatkan setelah penerapan blended-PBL. Analisis lebih lanjut menunjukkan bahwa sebelum penerapan blended-PBL, peserta didik tidak mampu mengidentifikasi istilah, mempertimbangkan definisi, dan tidak dapat memberikan penjelasan lebih lanjut. Selain itu, mereka juga kesulitan dalam menarik kesimpulan dari diskusi sehingga mereka tidak dapat menerapkan konsep yang berbeda masalah. Setelah menerapkan blended-PBL, mahasiswa dapat mengembangkan keterampilan Berpikir Kritis mereka sehingga dapat memberikan penjelasan sederhana, membangun keterampilan dasar, memberikan penjelasan lebih lanjut, menentukan pemecahan masalah tindakan dan dapat menarik kesimpulan dengan benar.

Hal inilah juga yang dapat dicermati dalam penelitian ini bahwa setelah dosen menggunakan model Blended-PBL ini respon mahasiswa dan juga suasana perkuliahan menjadi lebih kondusif sehingga mendukung peningkatan kemampuan berfikir kritis juga dilihat dari siklus penelitian khususnya siklus II.

\section{PENUTUP}

Berdasarkan hasil penelitian dan pembahasan, dapat disimpulkan bahwa pembelajaran dengan menggunakan model Blended-PBL mampu meningkatkan kemampuan berpikir kritis mahasiswa pada mata kuliah media pembelajaran Jurusan PGSD Universitas Negeri Padang. Hal ini dapat dilihat dari hasil rata - rata presentase kemampuan berpikir kritis yang diobservasi pada siklus I sampai dengan siklus II yang mengalami peningkatan hingga mencapai indikator keberhasilan. Berdasarkan hasil penelitian ini dapat dikemukakan saran bahwa perlu kiranya mencoba menggunakan model pembelajaran lainnya seperti problem posing maupun problem solving dan dalam pelaksanaan model Blended-PBL guna meningkatkan kemampuan berpikir kritis mahasiswa hendaknya mempertimbangkan kesesuaian materi, karena dibutuhkan waktu yang relatif panjang.

\section{DAFTAR PUSTAKA}

Arends, R. I., \& Kilcher, A. (2010). Teaching for student learning: Becoming an accomplished teacher. In Teaching for Student Learning: Becoming an Accomplished Teacher. https://doi.org/10.4324/9780203866771

Cazzola, M. (2008). Problem-based learning and Mathematics: Possible Synergical Actions. Proceeding, IATED (In- Ternational Association of Technology, Education and Development), Valencia, Spain, 2008. https://doi.org/ISBN: 97884-612-5091-2

Driscoll, M. (2002). Blended learning: Let's get beyond the hype. E-Learning.

Enis, R. H. (1993). Critical thinking assessment. Theory Into Practice. 
Etherington, M. (2011). Investigative primary science: A problem-based learning approach. Australian Journal of Teacher Education. https://doi.org/10.14221/ajte.2011v36n10.1

Garrison, D. R., \& Vaughan, N. D. (2012). Blended Learning in Higher Education: Framework, Principles, and Guidelines. In Blended Learning in Higher Education: Framework, Principles, and Guidelines. https://doi.org/10.1002/9781118269558

Graham, C. R. (2011). Blended Learning Models. In Encyclopedia of Information Science and Technology, Second Edition. https://doi.org/10.4018/978-1-60566026-4.ch063

Herliandry, L. D., Nurhasanah, Suban, M. E., \& Heru, K. (2020). Transformasi Media Pembelajaran Pada Masa Pandemi Covid-19. Jurnal Teknologi Pendidikan.

Hmelo-Silver, C. E., \& Barrows, H. S. (2006). Goals and Strategies of a Problem-based Learning Facilitator. Interdisciplinary Journal of Problem-Based Learning. https://doi.org/10.7771/1541-5015.1004

Holmes, N. G., Wieman, C. E., \& Bonn, D. A. (2015). Teaching critical thinking. Proceedings of the National Academy of Sciences of the United States of America. https://doi.org/10.1073/pnas.1505329112

Horvath, C. P., \& Forte, J. M. (2011). Critical thinking. In Critical Thinking. https://doi.org/10.5951/at.12.6.0501

Jandrić, P. (2020). Postdigital Research in the Time of Covid-19. Postdigital Science and Education. https://doi.org/10.1007/s42438-020-00113-8

Kemendikbud RI. (2014). Press workshop: Implementasi kurikulum 2013. Kementrian Pendidikan Dan Kebudayaan Republik Indonesia.

Kemmis, S., McTaggart, R., \& Nixon, R. (2014). The Action Research Planner. In The Action Research Planner. https://doi.org/10.1007/978-981-4560-67-2

KRISTINA PERONIKA NAIBAHO, P. J. S. (2020). PENGARUH KOMPETENSI PEDAGOGIK GURU TERHADAP HASIL BELAJAR IPA SISWA KELAS III SDN060915 JL. T.B SIMATUPANGKECAMATANMEDAN SUNGGAL TAHUN PEMBELAJARAN2018/2019. Jurnal Ilmiah Aquinas, 3(2), 306-315.

Lukitasari, M., Purnamasari, I., Utami, S., \& Sukri, A. (2019). Blended-Problem-Based Learning: How its impact on students' critical thinking skills? JPBI (Jurnal Pendidikan Biologi Indonesia). https://doi.org/10.22219/jpbi.v5i3.10048

Ommundsen, P. (2013). Problem-based learning. In Inspiring Students: Case Studies on Teaching Required Courses. https://doi.org/10.4324/9781315042169-9

Prayitno, W. (2015). Implementasi Blended Learning dalam Pembelajaran pada Pendidikan Dasar dan Menengah. Artikel LPMP D.I. Yogyakarta.

Putera, R. F., Anita, Y., \& Ladiva, H. B. (2018). Peningkatan Hasil Belajar Siswa Pada Pembelajaran Pendidikan Kewarganegaraan (PKn) Dengan Menggunakan Model Jigsaw Di Sekolah Dasar. Jurnal Inovasi Pendidikan Dan Pembelajaran Sekolah Dasar. https://doi.org/10.24036/jippsd.v2i1.100048

Putera, R. F., \& Qalbi, Z. (2020). Penggunaan Model GI (Group Investigation) pada Pembelajaran Pendidikan Kewarganegaraan di Sekolah Dasar. Jurnal Pendidikan. https://doi.org/10.31258/jp.11.1.20-32

Rose, R., \& Grosvenor, I. (2013). Action research. In Doing Research in Special Education: Ideas into Practice. https://doi.org/10.4324/9781315069173-8

Sari, Suci Perwita; Siregar, E. F. S. (2020). Pengaruh Model Pembelajaran Abad 21 4Cs Dalam Meningkatkan Keterampilan Membuat Pertanyaan Tingkat Tinggi Mahasiswa PGSD FKIP Pada Materi Gejala Alam T.A. 2019/2020. Jurnal Ilmiah 
Aquinas.

Sari, A. R. (2013). STRATEGI BLENDED LEARNING UNTUK PENINGKATAN KEMANDIRIAN BELAJAR DAN KEMAMPUAN CRITICAL THINKING MAHASISWA DI ERA DIGITAL. Jurnal Pendidikan Akuntansi Indonesia. https://doi.org/10.21831/jpai.v11i2.1689

Şendağ, S., \& Ferhan Odabaşi, H. (2009). Effects of an online problem based learning course on content knowledge acquisition and critical thinking skills. Computers and Education. https://doi.org/10.1016/j.compedu.2009.01.008

Shamim, T. (2017). Critical-thinking skills. In Journal of the American Dental Association. https://doi.org/10.1016/j.adaj.2016.11.006

Smaldino, P. E., \& McElreath, R. (2016). The natural selection of bad science. Royal Society Open Science. https://doi.org/10.1098/rsos.160384

Sudarman. (2007). Problem Based Learning: Suatu Model Pembelajaran untuk Mengembangkan dan Meningkatkan Kemampuan Memecahkan Masalah Sudarman. In jurnal pendidikan inovatif.

Sugiono. (2016). Metode Penelitan Kuantitatif, kualitatif dan R\&D. In Bandung: Alfabeta.

Sumarno. (2019). Pembelajaran Kompetensi Abad 21 Menghadapi Era Society 5.0. Penguatan Pendidikan Dan Kebudayaan Untuk Menyongsong Society 5.0.

Triyanto, S. A., Susilo, H., \& Rohman, F. (2016). Penerapan Blended-Problem Based Learning dalam Pembelajaran Biologi. Jurnal Pendidikan.

Wannapiroon, P. (2014). Development of Research-based Blended Learning Model to Enhance Graduate Students' Research Competency and Critical Thinking Skills. Procedia - Social and Behavioral Sciences. https://doi.org/10.1016/j.sbspro.2014.05.361

Wood, D. F. (2008). Problem based learning. In BMJ. https://doi.org/10.1136/bmj.39546.716053.80

Yaman, M., \& Graf, D. (2010). Evaluation of an international blended learning cooperation project in biology teacher education. Turkish Online Journal of Educational Technology.

Yazar Soyad,, B. B. (2015). Creative and Critical Thinking Skills in Problem-based Learning Environments. Journal of Gifted Education and Creativity. https://doi.org/10.18200/jgedc.2015214253

Zubaidah, S. (2018). Mengenal 4C: Learning and Innovation Skills untuk Menghadapi Era Revolusi Industri 4.0. 2nd Science Education National Conference. 